\title{
SERVICE QUALITY IN TOURISM MANAGEMENT: COMPARISON BETWEEN TRADITIONAL AND LOW-COST AIRLINES
}

\author{
Rojanard Waramontri
}

Suan Sunandha Rajabhat University, Bangkok, Thailand

The purpose of this study is to examine service quality and customer satisfaction in tourism management from the customer's perspective, and also to explore how perceived service quality affects customer satisfaction and loyalty-related behavior towards airlines, and whether the factors affecting service quality, customer satisfaction, and loyalty differ between full-service and low-cost airlines. A critical review of the related literature reveals that the airline industry has been struggling with many challenges: cutting costs, managing fluctuating demand, keeping up with tight quality requirements while trying to maintain superior services and satisfy the needs of various customer groups. The data has been collected through questionnaires based on the previous research. 89 surveys have been completed by the passengers who traveled by air in the previous three months. Traditional airlines' passengers have significantly higher perceived service quality and customer satisfaction. However, there is no significant difference in loyalty-related behavior. Overall, service quality has a significant influence on customer satisfaction for both traditional and low-cost airlines. However, the effect of service quality on behavioral intentions is only significant for traditional airlines. The results suggest that management of traditional and low-cost airlines should maintain service quality as it affects customer satisfaction.

Keywords: airline industry; low-cost airlines; customer satisfaction; perceived service quality; customer loyalty; customer behavior

\section{Introduction}

As competition in the service sectors is increasing all the time, the notion of service quality also becomes increasingly important because it is commonly recognized that providing a high-quality service retains customers and ensures survival and growth at the market (Dabholkar et al., 2000). Improving the quality of a service is a key concern in the

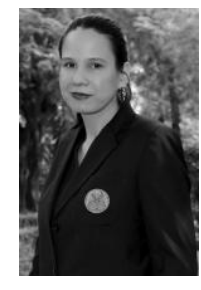

Rojanard Waramontri

MBA, lecturers at Airlines Business program, Suan Sunandha Rajabhat University, Bangkok, Thailand

Research interests: airlines services, hospitality and tourism, management in airline transportation

E-mail: rojanard.wa@ssru.ac.th 


\section{SERVICE QUALITY IN TOURISM MANAGEMENT}

airline industry (Hoffman \& Bateson, 2002). Previous research has shown that among various competitive variables for airlines such as fares, frequency, market access, and service quality, the latter is the most highly competitive variable (Banfe, 1992). Hence, the delivery of high service quality has become a marketing priority for service firms on their way to achieving success (Hoffman \& Bateson, 2002). This is particularly true for the airline industry as this sector is known to be extremely competitive. Moreover, a range of research studies has shown that, when all other things are equal, passengers respond the most to the quality of service (Lovelock \& Weinburg, 1993).

Therefore, managing service quality has become top priority in the airline industry (Wells \& Wensveen, 2004). One of the significant issues in today's airline industry is the growth of low-cost airlines (Atalik \& Özel, 2007). Apart from obviously lower cost (see the name), they are also characterized by point-to-point short-haul travel, no in-flight meals, and primarily direct sales. These airlines are not using service quality as their key competitive advantage. Instead, they appeal to the most cost-conscious market segments (Graham \& Vowels, 2006).

Airline managers need to know which factors affect passengers' choice of airlines. This study assesses service quality in the airline industry from the customers' perspective. The study explores how perceived service quality affects customer satisfaction and customer loyalty-related behavior. Moreover, it identifies whether the factors affecting service quality, customer satisfaction, and loyalty differ between full-service and low-cost airlines.

\section{Literature Review}

\section{Service quality}

Service quality is an important subject for both public and private sectors, but especially for business services industry. It is all about the extent to which a service meets or exceeds customer needs and expectations. During the past two decades, service quality has become a major area of attention for practitioners, managers and researchers because of its strong impact on business performance, lower costs, return on investment, customer satisfaction, customer loyalty and gaining higher profit.

Rapid development and competition in terms of service quality, in both developed and developing countries, has made it important for companies to measure and evaluate the quality of service they are providing. Several conceptual models have been developed by different researchers for measuring service quality. It is envisaged that conceptual models in service quality enable management to identify quality problems and thus help with planning and launch of quality improvement programs, thereby improving efficiency, profitability and performance overall.

There are two key aspects that describe and affect service quality - the actual service customers expected (the expected service) and services perceived (the perceived service). Although the definitions of service quality vary, they all are formulated from the customer perspective: what customers perceive as important dimensions of quality.

Dabholkar et al. (2000) tested a hierarchical conceptualization of retail service quality and proposed three levels for it: (1) customers' overall perceptions of service quality; (2) primary dimensions; and (3) sub-dimensions. 


\section{Customer satisfaction}

Satisfaction is consumer's fulfillment response. It is a judgment that a product, a service or one of their features get in terms of pleasurable level of consumption-related fulfillment, including the levels of under- or over-fulfillment. Satisfaction is an "overall customer attitude towards a service provider"'or it can be seen as an emotional reaction to the difference between what customers anticipate and what they actually receive. When customers are satisfied, they are more likely to return, while dissatisfied customers are more likely to go elsewhere.

Moreover, to achieve a high level of customer satisfaction, most researchers suggest that a high level of service quality should be delivered by the service provider as service quality is normally considered as an antecedent of customer satisfaction. Interpretations of the role of service quality and satisfaction have varied considerably. Many authors confined satisfaction to relate to a specific transaction while service quality was defined as an attitude. This meant that perceived service quality was a global judgment, or attitude, relating to the superiority of a service.

Adding to the debate on the distinction between service quality and satisfaction, customer satisfaction has also been operationalized as a multidimensional construct along with the same dimensions that constitute service quality. Quality of a service has become an aspect of customer satisfaction.

Satisfaction and service quality have certain things in common, but satisfaction is generally a much broader concept, whereas service quality focuses specifically on the dimensions of service. Amidst these debates, it is clear that there is a strong relationship between service quality and customer satisfaction, thus, it can be concluded that service quality has significant impacts on customer satisfaction.

The purpose of this study is to examine service quality and customer satisfaction in tourism management from the customers' perspective. Based on the objectives of the study, the following four hypotheses have been formulated:

H1: Service quality dimension "Reliability" has a positive influence on customers' overall perception of service quality .

$\mathrm{H} 2$ : Service quality dimension "Assurance" has a positive influence on customers' overall perception of service quality.

H3: Service quality dimension "Tangibles" has a positive influence on customers' overall perception of service quality.

H4: Service quality dimension "Empathy" has a positive influence on customers' overall perception of service quality.

\section{Methodology}

A self-administered questionnaire was selected as the key research tool for this study. The questionnaire was designed on the basis of previous work: a) a refined SERVQUAL to fit the airline industry as used by Gilbert and Wong (2003); and b) airline industry-based dimensions. The questionnaire consists of three parts. Part A contains questions regarding the respondents' demographic profiles and their latest flight experience. 


\section{SERVICE QUALITY IN TOURISM MANAGEMENT}

The respondents have been asked which kind of airlines they used (traditional or lowcost ones), the purpose of their trip, the number of times they travel by air every year, as well as their age group and gender.

Part B consisted of 15 questions that measure the airline's service quality from the passenger's point of view. It includes the five SERVQUAL dimensions: Tangibles, Reliability, Responsiveness, Assurance, and Empathy, with each dimension having three questions.

Part C examined the overall assessment of airline service. It included the overall perception of service quality, the level of satisfaction, and future behavioral intentions (intention to reuse and recommend to friends and family). Questions in Parts B and C used a 7-point Likert scale.

The target population was people who have traveled by air in the previous three months. These passengers are more likely to remember their perceptions of service quality and flight experience. Nonprobability sampling, specifically convenient sampling, was chosen. The field survey was conducted in September 2019 in Don Mueang and Suvarnabhumi airports, Thailand. 89 useful questionnaires were collected.

Data collected from these questionnaires was then analyzed by means of SPSS 16.0 for Windows. Before analyzing the data, Cronbach's alpha was used to test the reliability of data. The closer Cronbach's is to 1, the higher is the internal consistency reliability.

All four hypotheses were tested by means of multiple regression analysis. Multiple regression analysis is a statistical technique that analyzes the linear relationship between a dependent variable and multiple independent variables by estimating the coefficients for the equation for a straight line (Hair et al., 1998).

\section{Findings of the Study}

The total of $t 89$ respondents participated in our research.

Of them, 47 were female and 42 were male; $44 \%$ of the respondents were aged between 25 and 34, 20\% - under 25 years old, $22 \%$ - from 35 to 44 years old, 9\% - from 45 to 54 , and finally $5 \%$ were over 54 years old. 46 respondents had used traditional airlines for their latest air travel and 43 preferred low-cost airlines. $65 \%$ of the respondents travelled for leisure whereas $18 \%$ were visiting friends or family, $13 \%$ were going somewhere for business, and $4 \%$ - for other reasons, such as education, attending a fair, etc.

The respondents who had traveled by air once in the last 12 months represented $24 \%$, $20 \%$ of the surveyed had traveled by air twice in the previous year, $24 \%$ and $16 \%$ had traveled 3 and 4 times respectively, and 16\% — more than four times.

\section{Descriptive Statistics of the Service Quality Dimensions}

For "Tangibility," all three mean scores for traditional airlines were higher than those of low-cost airlines. The lowest score was for comfortable in-flight seats. When the difference between traditional and low-cost airlines was tested by the independent samples ttest, there were significant differences for all the items (sig. value $=0.000$ ). Traditional airlines showed higher mean scores than low-cost airlines for all the three items of "Reliability." Both had the highest mean score for "on-time departure and arrival" and the lowest - for "providing good service consistently." Again, the differences of the mean scores were significant. The mean scores of traditional airlines for all the three items of 
"Responsiveness" were higher than those of the low-cost airlines and the differences were significant. Traditional airlines had the lowest mean score for "efficient check-in and baggage handling service" and also the highest mean score for "prompt service." On the other hand, low-cost airlines had the lowest mean for the parameter "willing to help".

For "Assurance," the mean scores of traditional airlines were higher than those of lowcost airlines, and the difference was statistically significant. For traditional airlines, "polite" had the highest mean score and "employees have knowledge to answer" somehow got the lowest. Low-cost airlines passengers demonstrated the lowest agreement with "Safe" and the highest for "Employees are polite". All the mean scores for traditional airlines were significantly higher than those of low-cost airlines in what concerns "Empathy." Both groups of airlines had the lowest score for individual attention and the highest - for convenient schedules. Low-cost airlines' passengers had the lowest perception on "Tangibles", whereas traditional airlines' passengers - for "Empathy." Both groups of airlines' passengers reached the highest agreement on "Reliability."

\section{Descriptive Statistics of Overall Assessment}

Traditional airlines had the highest mean score for the overall service quality whereas low-cost airlines had the lowest mean scores for all four items. This result supports the idea that most traditional airlines set good service quality as their top priority while low-cost airlines focus on other factors. Among the four assessment items for low-cost airlines, the highest was the "intention to reuse." This suggests that low-cost airlines' passengers had the intentions to repurchase low-cost plane tickets, even though they had relatively low perceived service quality and satisfaction. The differences between traditional and low-cost airlines were statistically significant in part of "Service Quality" and "Customer Satisfaction" (sig. value $=0.000$ ). However, the difference was not significant for behavioral intentions as the sig. value was over 0.05 . Cronbach's alpha values were 0.78 and 0.82 . This suggests good internal consistency and reliability. Thus, there was no need to remove any item to improve reliability.

\section{Hypotheses Testing}

\section{Relationship Between Dimensions and Service Quality}

The five service quality dimensions were set as the independent variables and "overall service quality" - as the dependent variable. The regression analysis for traditional and lowcost airlines was conducted separately and the results were then compared. The regression was statistically significant $(\mathrm{p}=0.000)$. The $\mathrm{R} 2$ value tells us how much of the variance in the dependent variable is explained by the model. This model explained $81 \%$ of the variance in service quality. Only one independent variable, "Assurance" (sig. value $=0.000$ ), makes a statistically significant unique contribution to the overall service quality.

From the multiple regression analysis between SERVQUAL dimensions and perceived service quality of low-cost airlines, it was found that the two independent variables, "Tangibles" and "Assurance" (sig. value $=0.000$ ), make statistically significant unique contributions to the overall service quality. The other three dimensions do not have statistically significant influence on service quality of the low-cost airlines. Based on these two regression results, it can be concluded that $\mathrm{H} 1$ and $\mathrm{H} 4$ are rejected and $\mathrm{H} 3$ is partially accepted (only for the low-cost airlines). H2 is fully supported. 


\section{SERVICE QUALITY IN TOURISM MANAGEMENT}

\section{Summary of the Hypotheses Testing Results}

H1: Service quality dimension "Reliability" has a positive influence on customers' overall perception of service quality - Rejected.

H2: Service quality dimension "Assurance" has a positive influence on customers' overall perception of service quality - Accepted.

H3: Service quality dimension "Tangibles" has a positive influence on customers' overall perception of service quality - Partially accepted.

H4: Service quality dimension "Empathy" has a positive influence on customers' overall perception of service quality — Rejected.

\section{Conclusions}

The goodness of data in terms of reliability was assessed by means of Cronbach's alpha. Traditional airlines passengers scored all five service quality dimensions, overall service quality, customer satisfaction, and behavioral intentions higher. Standard multiple regression analysis was executed to test $\mathrm{H} 1$. Only "Assurance" shows a significant influence on the overall perceived service quality for both traditional and low-cost airlines. "Tangibles" significantly influenced service quality of the low-cost airlines. The other dimensions did not have significant influence on service quality. It was found that service quality significantly and positively influenced customer satisfaction in case of both traditional and low-cost airlines. However, behavioral intentions were significantly affected by service quality only in traditional airlines. The differences between the two categories of airlines were significant in part of "Service Quality" and "Customer Satisfaction," whereas there was no significant difference in terms of "Intention to reuse" and "Intention to recommend."

The main findings of the study are: (1) Traditional airlines' passengers perceive service quality significantly higher than low-cost airlines' passengers, for all five service quality dimensions; (2) Traditional airlines' passengers have significantly higher overall perceived quality and customer satisfaction than low-cost airlines' passengers; (3) There is no significant difference in behavioral intentions such as the "intention to reuse" and the "intention to recommend to friends/family" between traditional and low-cost airlines; (4) Both traditional and low-cost airlines' passengers gave the highest score assigned to "Reliability" among the five service quality dimensions; (5) Traditional airlines' passengers assigned the lowest score to "Empathy" while low-cost airlines' passengers — to "Tangibles"; (6) Among service quality dimensions, "Assurance" has significant influence on the overall service quality of traditional airlines; and (7) "Tangibles" and "Assurance" had significant influences on the overall service quality of low-cost airlines.

This study provides better understanding of service quality in the context of the airline industry, low-cost sector in particular. Although low-cost airlines' top priority is not high quality service, they still need to meet customer expectations. By identifying customer assessment of service quality and the main factors affecting customer satisfaction and loyalty, airlines will be able to maintain their competitive advantages by enhancing their strengths and improving their weak areas. In particular, by comparing and identifying the differences between traditional full service and low-cost airlines, this study might become valuable help with marketing strategies, specifically with understanding how to differentiate and maintain competitive advantages. 


\section{Recommendations}

The results of this study indicate that passengers' perception and evaluation of traditional and low-cost airlines are significantly different in general. Also, perceived service quality affects customer satisfaction in both traditional and low-cost airlines. According to our findings, Empathy in this study means "caring, individualized attention the airline provides to its customers". Thus, traditional airlines should pay more individual attention to passengers and try to customize services to meet their various needs.

"Tangibles" significantly influence the overall perceived service quality of low-cost airlines. This category of airlines may not be able to offer comfortable seats or good in-flight facilities as their business model is all about "simplifying" and "lower price." However, if they could differentiate their tangible facilities such as in-flight seats and interiors, they can have competitive advantages, at least over other low-cost airline competitors.

Next, the "Assurance" dimension significantly affects the overall service quality for both traditional and low-cost airlines. In particular, low-cost airlines' passengers have very low perception in part of "feeling safe during the flight." Thus, flight safety must be assured and flight staff needs to be knowledgeable to answer all possible passenger inquiries regarding safety and security.

Lastly, it was found that the overall service quality positively affects customer satisfaction in both traditional and low-cost airlines. In particular, service quality significantly influences behavioral intentions such as the intention to reuse and/or recommend traditional airlines. Thus, traditional airlines should improve and manage their service quality as it is positively affecting both customer satisfaction and customer loyalty.

Further research could be conducted to identify different perceptions towards service quality among more diverse demographic groups in terms of age, frequency of flight, income level, nationality, and so forth. Using scales designed specifically for airlines should provide results with higher levels of reliability and validity.

\section{References:}

Aksoy, S., Atilgan, E. \& Akinci, S. (2003). Airline services marketing by domestic and foreign firms: Differences from the customers' viewpoint. Journal of Air Transport Management, 9, 343351.

Atalik, Ö. \& Özel, E. (2007). Passenger expectations and factors affecting their choice of low cost carriers: Pegasus Airlines. In: Proceedings of the Northeast Business \& Economics Association. Central Connecticut University.

Banfe, C. F. (1992). Airline management. Englewood Cliffs, NJ: Prentice Hall.

Dabholkar, P. A., Shepherd, C. D. \& Thorpe, D. I. (2000). A comprehensive framework for service quality: An investigation of critical conceptual and measurement issues through a longitudinal study. Journal of Retailing, 76(2), 139-173.

Gilbert, D. \& Wong, R. K. C. (2003). Passenger expectations and airline services: A Hong Kong based study. Tourism Management, 24, 519-532.

Graham, B. \& Vowels, T. M. (2006). Carriers within carriers: A strategic response to low-cost airline competition. Transport Reviews, 26(1), 105-126. 


\section{SERVICE QUALITY IN TOURISM MANAGEMENT}

Hair, J., Anderson, R., Tatham, R. \& Black, W. (1998). Multivariate data analysis. Englewood Cliffs, NJ: Prentice Hall.

Hoffman, K. D. \& Bateson, J. E. G. (2002). Essentials of services marketing: Concepts, strategies, and cases. Fort Worth, TX.

Lovelock, C. H. \& Weinberg, C. B. (1993). Marketing challenges: Cases \& exercises. New York: McGraw.

Paper submitted

Paper accepted for publishing

Paper published online
02 November 2020

26 November 2020

31 January 2021 